Technological University Dublin

DÜBLIN

ARROW@TU Dublin

2007-06-01

\title{
Key Skills Framework: Enhancing Employability Within a Lifelong Learning Paradigm
}

\author{
Aidan Kenny \\ Technological University Dublin, aidan.kenny@tudublin.ie \\ Ray English \\ Technological University Dubin \\ Dave Kilmartin \\ Technological University Dubin
}

Follow this and additional works at: https://arrow.tudublin.ie/cserart

Part of the Educational Assessment, Evaluation, and Research Commons

\section{Recommended Citation}

Kenny, A., English, R. \& D. Kilmartin. (2007) Key skills framework: enhancing employability within a lifelong learning paradigm. Level3, issue 5. doi:10.2139/ssrn.960942

This Article is brought to you for free and open access by the Centre for Social and Educational Research at ARROW@TU Dublin. It has been accepted for inclusion in Articles by an authorized administrator of ARROW@TU Dublin. For more information, please contact arrow.admin@tudublin.ie, aisling.coyne@tudublin.ie, gerard.connolly@tudublin.ie.

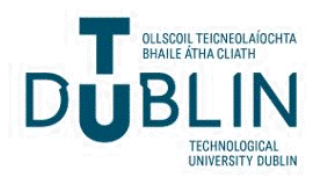


Dublin Institute of Technology

ARROW@DIT

2007-06-01

\section{Key skills:enhancing employability within a lifelong learning paradigm}

Aidan Kenny

Dublin Institute of Technology

Ray English

Dublin Institute of Technology

Dave Kilmartin

Dublin Institute of Technology

\section{Recommended Citation}

Kenny, Aidan; English, Ray; and Kilmartin, Dave, "Key skills:enhancing employability within a lifelong learning paradigm" (2007). Articles. Paper 2.

http://arrow.dit.ie/dirreart/2 


\section{Key Skills Framework}

Enhancing employability within a lifelong learning paradigm

Aidan Kenny, Ray English, Dave Kilmartin

A working paper by the Skills Research Initiative

A prior version of this paper was accepted for presentation at the International Technology Education and Development (INTED) annual conference 2007. 


\begin{abstract}
Employability ${ }^{1}$ has become an area of interest among the general public and policy makers alike, with an increasing number of reports in the general media regarding the need for workers in certain sectors to up-skill due to the possible threat of job 'displacement'. In addition, there has been an increase in education and training policy documents emphasising that citizens should pursue Lifelong Learning ${ }^{2} /$ Life Wide Learning to address the increased job-related uncertainty attributed to the globalisation process and the concomitant competitive threats. Academics such as Barnett (2005) claim that we are living in an era of 'super complexity' ${ }^{3}$ and rapid change where even trade unions are beginning to come to terms with the notion that in the present employment climate 'change is a given rather than an exception'. Within this framework of change, of global economics, of mobility of capital and labour, and of social flux, the Irish economy has outperformed many of her fellow European Union (EU) member states in terms of both GDP and GNP. ${ }^{4}$ However, the pertinent question now posed is how will Ireland maintain this competitive advantage moving forward? While the answer to this question is multi-dimensional and complex, requiring expert input from various academics, professional bodies and other interested parties, there is nonetheless a growing acceptance that education and training are fundamental to the development of a sustainable solution. This working paper presents a conceptual framework and signposts a research process presently being utilised by a research team to explore employability and a social construct. As such, the reader is presented with emergent work and invited to contribute to this early stage of the research process.
\end{abstract}

\title{
Conceptual approach
}

The purpose of this paper is to describe an emergent work from the Skills Research Initiative (SRI) portfolio of research projects, namely 'Key Skills Framework:

Enhancing employability within a lifelong learning paradigm'. The aim of this research project is to develop, pilot, evaluate and then mainstream a Key Skills Learning model for up-skilling the emergent workforce in terms of generic transferable skills, ${ }^{5}$ thereby enhancing employability. The intention is to:

- Critically review and identify the key generic skills that students, workers, employers and experts consider necessary in this new global employment environment.

- Produce, pilot and mainstream a high-value, quality assured Key Skills Learning module that fulfils the criteria of a Special Purpose Award Type at Level $6^{6}$ of the National Framework of Qualifications (NFQ), as detailed in NQAI policy documents.

- To use a blended learning methodology to deliver a flexible, user-friendly education and training package which covers the identified key skills.

The function of this paper is dissemination and dialogue. The SRI recognise that research reports and papers are usually presented ex post; here we are presenting work ex ante. By adopting this approaching the SRI is endeavouring to establish a communication dynamic with interested parties external to the research. The aim is to share and exchange knowledge and experience relating to employability with our peers and communities of practice. The three main areas covered in this paper are: 
1 the initial stage of a systematic review of the literature relating to employability;

2 a provisional outline of a conceptual framework for research into employability;

3 DIT as a case study site and how employability could enhance the learning and human capital of both undergraduate and apprenticeship students.

The mode of enquiry utilised for this paper is interpretative, the methodology is located in qualitative research discourse and the method consists of literature review, document analysis and 'critical self-reflection'7 as actors in the Higher Education (HE) sector. The 'multi-disciplinary' (see Rowland 2006) research team adopt an eclectic position regarding knowledge domains, ${ }^{8}$ utilising research from several disciplines in the broad episteme of social science. Within the limited space available here we seek to provide an initial literature review which should be considered as a 'work in progress', our intent being to identify what Guba and Lincoln (1989) term 'claims, concerns and issues'. ${ }^{9}$ These will be confined to three areas of discourse. First, policy, or the scouring and mapping out of some of the macro (international), meso (European) and micro (Irish) policy initiatives and reports drafted by governments and policy shapers ${ }^{10}$ which promote employability; we refer to this cluster of policy items as the 'official employability discourse'. Second, simultaneously using a 'snowball' technique we are trawling through peer-reviewed journals to make visible the diverse voice of academics, teachers, trainers and researchers, a method we categorise loosely as the 'non-aligned employability discourse'. Finally, we endeavour to signpost some of the views of the more influential lobby groups, students' unions, professional associations, trade unions and specialist interest organisations, which we will refer to as 'insular employability discourse'. The literature review process utilised is informed by the work of Hart (2005) and Creswell (2005), namely the five key stages identified as part of a literature review:

1 identify key terms

2 locate literature

3 critically evaluate and select

4 organise literature

5 write the review

Other ideas were obtained from Fisher (2006).

\section{The (new) organisation of work and employability}

In modern Western industrialised societies it is now generally accepted that the expectation of 'lifetime employment', '11 'single employment' or continuous employment in the one specialised field is the exception rather than the norm. While working environments have greatly improved in terms of pay and conditions, the reverse side of the coin is insecurity of employment. With the introduction of part-time, short-term and fixed-term contracts, job sharing, contracting out work, project work and so forth, employees need to have the ability to cope with change. Some theorists (Sabel 1982; Brehony and Deem 2005) claim that work organisation in modern industrial societies has moved from 'Fordism', which is characterised by scientific management techniques, hierarchical structure, inflexible processes, specialisation and mass production, to 'post Fordism', which places an emphasis on, flexibility, decentralisation, 
team work, flat structure and information communications technology (ICT) utilisation. Harvey (2000) claims that graduates were facing new realities in the organisation of work due to three main organisational change strategies: downsizing: de-layering; and flexible contractual arrangements. Other more politically driven explanations highlight the incremental advancement of the neoliberal agenda which can be located in the ideology promoted by Reaganism and Thatcherism during the 1970-80s in the USA and the UK (see Beck 1999).

The neoliberal political agenda has become a dominant ideology pursued by European political parties, bureaucrats and technocrats. As such it is reshaping the education landscape throughout Europe. The overarching principles of neoliberalism are free trade, free capital mobility, the growing flexibility of labour, privatisation, restructuring of the welfare state, market economics and the movement of responsibility/choice from the state to the individual (see Hermann 2005). In an educational context neoliberalism refocuses the pedagogical discourse relating to vocationalism versus liberal education (see Pring 1996). The emergent dominant official policy inherent in this modernisation agenda targeting education places a distinct emphasis on the economic imperative of education, namely the return on investment or human capital theory (Becker 1964), and as such it leans towards 'utilitarianism' (Halstead 1996). If the post-Fordism and neoliberal thesis is accepted then the notion of employability could be perceived as a useful construct that could assist the policy formulation process with a view to preparing and equipping students/workers ${ }^{12}$ with skills in advance of the demand posed by the new reorganisation of work. It gives recognition to the new nature of work - mainly uncertainty - which workers are experiencing. An employability approach within this context seeks to develop strategies and capabilities that assist workers to 'gain and maintain' employment by learning new transferable skills (see Hillage and Pollard 1998). Morley (2001) terms this process 'Producing new of workers'. She is critical of the motives behind the employability policy agenda, both in a political and philosophical sense, claiming that education is being 'Japanised', incorporating the values and approaches of industry and accepting the utilitarian education needs of modern capitalism. Further, she suggests that the employability agenda is a 'decontextualised signifier' failing to cater for issues such as gender, race, social class and disability. Sanders and de Grip (2003), in their study on low-skilled workers in the Netherlands, postulate the emergence and shift of emphasis in the employability agenda. Below we provide a snapshot of their work:

$\begin{array}{ll}\text { 1950-60s 'individuals potential to become employed and attitude' } \\ 1970 \mathrm{~s} & \text { 'occupational knowledge and skills, ability' } \\ 1980 \mathrm{~s} & \text { 'meta-characteristics, attitude, knowledge, skills and career' } \\ 1990 \mathrm{~s} & \text { 'career focus, ability, capacity to deal with change' }\end{array}$

This provides an interesting illustration of retrospective reflection and how the emphasis has changed from the broad notion of the individual's potential to the more narrow focus of career path. Of course there are other dynamic and complex factors at play here shaping these changes, such as geo-politics, socio-economic and technological factors and, as Giddens (2004b) notes during the above time frame, the 'reduction in time and space' due to advances in technologies and access to mass transportation.

Before moving on it is necessary to explore some definitions of employability and the main interrelated tenets explicitly inherent in this concept. The UK, France, 
Germany ${ }^{13}$ Australia and the USA have being promoting the concept of employability and developing skills categories since the 1980s. The USA, Australia and the UK use the following descriptive words - 'core', 'generic', 'key' - skills that are considered essential for employability. Table 1 gives an example of the categorisation used by other countries and terminology used in relation to employability skills. It provides a researcher with an interesting linguistic perspective for a discourse analysis study relating to the expectations, priority and value that different countries place on employability skills. However this is outside the remit of this paper.

\section{Box l: Terms used in various countries to describe generic skills}

$\begin{array}{ll}\text { United Kingdom } & \text { Core skills, key sbills, common skills } \\ \text { Naw Zealand } & \text { Essential skills } \\ \text { Australia } & \text { Key competencies, employability skills, generic skills } \\ \text { Canada } & \text { Employability skills } \\ \text { United States } & \text { Basic skills, necessary skilk, workplace know-how } \\ \text { Simpapore } & \text { Critical enatling skills } \\ \text { France } & \text { Transferatle skills } \\ \text { Germany } & \text { Key qualifications } \\ \text { Switzerland } & \text { Trans-disciplinary goals } \\ \text { Denmark } & \text { Process independent qualifications }\end{array}$

Table 1 Terminology relating to employability skills as used in different countries Source: Australian National Training Authority (2003)

Official discourse in the $\mathrm{UK}^{14}$ which was underpinned by the 'New Deal', a socio-economic political policy advanced by the New Labour Government in the 1990s, viewed skills development as crucial to enabling employment participation, gaining an economic advantage and contribution to the larger vision of a knowledge economy. The UK Department of Education and Skills (see also Dearing Report 1997) have identified six key generic skills relevant to employability which they want incorporated into the curriculum. Further, employability is now used as one of a selection of performance indicators ${ }^{15}$ which claim to measure output effectiveness and which are utilised in the compilation of school, college and university league tables. Currently the six key generic skills in use are:

- communication

- application of numbers

- information technology

- working with others

- improving own learning and performance

- problem solving

Yorke (2006: 146) is somewhat dismissive of the transferable skills literature and its application to theories of learning, suggesting that it is 'little more than a wish list constructed by interested parties'. He notes the complexity of employability as a concept that seeks to explore and capture 'personal qualities, beliefs, understanding, skilful practices and the ability to reflect productively on experience'. He suggest two models that have pedagogical relevance: Bennett et al. (2000) and their differentiation of skills applicable to different domains and the specificity of skills to either a specific 
discipline or across disciplines. As such they identify five categories for curriculum design consideration:
disciplinary content
disciplinary skill
3 workplace experience
4 workplace awareness
5 generic skills

Yorke and Knight, in their 2004 'Skills plus project', propose an interrelated model called USEM (Understanding, Skills, Efficacy, and Metacognition) (see Yorke and Knight 2006). They claim the self-efficacy of the learner is crucial in the dynamic interaction of 'skilful practice' and 'subject understanding', and metacognition, or the process of reflecting 'on, in and for action'. This type of pedagogical approach to employability brings the needs of the student/worker to the centre stage and relegates the economic imperative as such to the outer arena. This is a more humanistic position: the students/workers are perceived as humans first, with unique individual characteristics, and only secondly as contributors to the techno-rationality ${ }^{16}$ of the new organisation of work. It is also worth noting in light of a pedagogical approach to employability which recognises the complex nature of this conceptual construct that several questions can be raised relating to current policy trends; What is the main driving force behind the employability agenda? Is employability a new policy instrument or a verifiable construct based on rigorous evidence? Is employability quantifiable? Can employability be measured as an output by performance indicators? Who are the main beneficiaries of employability - the state, industry, the individual? Who should fund the research needed to inform programme development? Who should fund the learning and teaching provision?

Sheldon and Thornthwaite's 2005 research into vocational education and training (VET) and employability skills in Australia offers some insight into the abovementioned questions. They suggest that emergent skills gaps are a factor in the advancement of the employability agenda, the main driver seeming to be political and economic agendas. They note that the current skills gap (shortages) has occurred as a result of mainstream VET underfunding ${ }^{17}$ and a new neoliberal political policy agenda, 'privatisation, corporatisation and the shrinking of public sector instrumentalities'.

Subsequently responsibility for VET provision has moved from the state 'traditional provider-led system' to a free market or 'industry-led system'. Currently there exists a lack of willingness by industry to make a serious sustainable financial contribution to VET and a myopic strategic vision of training provision that basically forfeits long-term VET planning and uses short-term migrant labour while negating industry responsibility by claiming that the individual worker is the benefactor of VET and therefore it is their responsibility to up-skill an individualisation approach. Thus, it is powerful industry interest groups and large private training providers who are setting the employability agenda and the 'wish list' of basic, personal and inter-personal skills that are necessary for the modern worker to make a positive and compliant contribution to the productivity and efficiency of the company, all of which leads back to Yorke's original thesis.

Another factor to note is the substantial psychometric literature and indeed a growing industry that offers sophisticated tests, claiming to measure individual differences, such as IQ, personality, attitudes, emotion and so forth. Such tests are used 
by large corporations, government agencies and other sectors for selection purposes. There does exist some conceptual crossover between the employability discourse and the items identified in psychometric and general psychological tests - the StanfordBinet IQ battery, Sternberg's concept of Multiple Intelligences, Goleman's concept of Emotional Intelligence (EQ), Cattell's Personality Factor test the 16PF, the Eysenck Personality Questionnaire (EPQ), Costa and McCrae's NEO-PI Five Factors - and we could broaden this out to include Belbin's test of characteristics of effective teams and other social psychology experiments on group dynamics. At this point in our review of research from the 'non-aligned discourse', the employability agenda crosses traditional tertiary education and training boundaries, VET, Further Education (FE) and HE. However, the emphasis is on those skills inherent to employability, with change depending on the sector and its requirements and needs (Yorke's 'wish list'). ${ }^{18}$ The conceptual potency of employability as a definitive construct seems to be based more on economic-political motives than empirical evidence and pedagogy.

\section{Micro perspective: Irish national policy context}

While the Irish economy is currently experiencing skills shortages and skills gaps in certain areas, ${ }^{19}$ policy makers, employers and trade unions have identified the upskilling of resident workers as crucial to the development of a strong economy. As Ms Anne Heraty, Chairperson, Expert Group on Future Skills Needs (EGFSN), claims: 'The up-skilling and training of the resident population must be seen as the primary response to skill shortages. Developing the work force at all levels is crucial to Ireland's sustained economic development (EGFSN 2005: 4).

While specialised up-skilling programmes can be provided in the workplace, for example training in the utilisation of new equipment, this source of up-skilling is specific and non-transferable; it benefits the employer and worker only in the immediate term. While these specialised specific skills are extremely necessary, they should be underpinned by the development of a broader, long-term strategic planning such as the adoption of a 'generic skills' up-skilling policy. This would benefit both the employer and the worker; the employer gains a worker with increased knowledge capital and the worker improves their human capital, transferable skills and therefore employability potential. This point is given a meso perspective in the Irish Progress Report 'Modernisation of Education and Training 2010':

In order to maintain and enhance Ireland's international competitiveness, ensuring that the education and training systems promote the development of human capital, especially through the identification of future key skills needs and the putting in place of appropriate related learning opportunities.

The National Development Plan (NDP) 2000-2006, ${ }^{20}$ launched in 1999, represented the largest investment plan in the history of the Irish State at that time. The main objective is the promotion of sustainable economic growth and employment. According to a statement by Minister Micheál Martin, about the NDP:

...education had been established as a key priority by the Government and ... the National Development Plan represents the unprecedented underpinning and expansion of programmes across the next seven years. 'I believe that this ambitious Plan provides an excellent foundation for delivering a high-quality and inclusive education system over the coming years.' The number 
of education issues covered by the Plan has greatly expanded from its predecessor and funding is very clearly focussed on national priorities. These are:

- To tackle disadvantage through a range of interventions at different levels

- To promote and support a culture of lifelong learning with a clear emphasis on second-chance education

- $\quad$ To modernise facilities and promote quality at all levels.

(15 November 1999, NDP 2000-2006)

The plan set out a $€ 57$ billion investment programme targeting key areas that impact on national competitiveness, such as infrastructure development, education and training, the productive sector, promotion of social inclusion and regional development. There was a substantial commitment made towards investment in education and training, with particular emphases on lifelong learning and 'second chance education'. The premise was that to maintain Ireland's economic performance in a rapidly changing and increasingly competitive globalised world, resources have to be targeted at people to enhance 'stock knowledge' and 'human capital'. The Enterprise Strategy Group ${ }^{21}$ suggests that:

From an enterprise perspective, the ability of the education system to respond flexibly to economic and social change is critical to the supply of appropriate skills for the effective functioning of the economy. Ireland's economic development will depend to a large degree on knowledge and innovation, both of which are essential in making the transition to higher value activities that support economic growth and wealth creation. People are the enablers of such activities and the education and training system must adapt to produce the skills to drive successful enterprise.

The above quotation demonstrates the economic perspective for the role of VET, FE and HE in the knowledge-based economy. The approach that this report adopts is an example of the general 'neoliberal' (see Lynch 2006b; Young 2005) economic model of education proposed by numerous interested parties or stakeholders. The general assumption is based in the 'human capital' (Becker 1964) economic paradigm, with its emphasis on gaining an economic return and competitive advantage on investment made in the spheres of education and training. The Operational Programme for Employment and Human Resources 2000-2006 also focuses on the human capital model. Three areas for skills development in the Third Level are targeted for investment: Middle-level Technician/Higher Technical and Business Skills, Undergraduate Skills and Institute Trainee Programme. An emphasis is placed on developing links between business and education and training providers to address skills shortages. This has implications with regards to mature applicants (workers, unemployed) gaining access to education and training programmes that are suitable to meet their requirements. The new NDP 2007-2013 (launched just before the submission deadline of this paper) will invest $€ 183.7$ billion in five priority areas: economic infrastructure, $€ 54.7$ billion; enterprise, science and innovation, $€ 22$ billion; human capital, $€ 25.8$ billion; social infrastructure, $€ 33.6$ billion; and social inclusion, $€ 49.6$ billion. Skills development, enhancement and up-skilling is mentioned throughout the document and particular emphasis is placed on investing in primary and secondary education, VET, FE and HE. (See Chap. 9, 'Human capital priority': 189-206; see also Appendix 2 for extracts from both NDP 2000-2006 relating to employability and NDP 2007-2013 to human capital.)

\section{Meso perspective: European policy context}


In the European context several policy documents have stressed the need for up-skilling and employability, with particular emphases on the EU becoming the most competitive economy in the world by 2010. Strategies are aimed at mobility, access to education and training, improving both basic and key skills levels, increasing the number of $\mathrm{PhD}$ and post-doctoral researchers, and recognition and translation of awards through the provision of a meta-framework (the European Qualifications Framework (EQF)). Other important initiatives include: Lisbon Agenda 2010, Bologna Process, Copenhagen Declaration, European Research Area, European Higher Education Area, and subsequent follow-up progress reports. Two new major initiatives for 2007-2013 are the Lifelong Learning programme and the Platform 7 research funding programme. The extract below gives an example of the policy trend being pursued by the EU Commission: ${ }^{22}$

The Council has repeatedly emphasised the dual role - social and economic - of education and training systems. Education and training are a determining factor in each country's potential for excellence, innovation and competitiveness. At the same time, they are an integral part of the social dimension of Europe, because they transmit values of solidarity, equal opportunities and social participation, while also producing positive effects on health, crime, the environment, democratisation and general quality of life. All citizens need to acquire and continually update their knowledge, skills and competences through lifelong learning, and the specific needs of those at risk of social exclusion need to be taken into account. This will help to raise labour force participation and economic growth, while ensuring social cohesion. Investing in education and training has a price, but high private, economic and social returns in the medium and long-term outweigh the costs. Reforms should therefore continue to seek synergies between economic and social policy objectives, which are in fact mutually reinforcing.

(EU Commission 2005: 3)

The SRI project will use the above-mentioned EU documents as points of references and as leads into other policy areas and will undertake a full document analysis of the collected documents. The project will endeavour to produce Key Skills Learning Modules that are in alignment with policy trends in both a European and national context. A primary aim will be to give citizens access to learning tools that will enable their employability potential. A second aim is to provide a positive learning experience that will encourage citizens to engage in FE and training, (a lifelong learning cycle). This will offer some protection in the now rapidly changing work environment.

\section{Macro perspective on employability}

From a macro perspective, utilising global context, employability as a construct is firmly on the agenda, specifically in relation to international organisations that seek to influence policy formation and implementation within different nation states. Here we identify some of the major international agencies that influence the global employability agenda.

The World Trade Organization (WTO) is a prime example. It first sought to negotiate binding legal international agreements relating to trade (import and exports) through the General Agreement on Trade and Tariffs (GATT) in 1996 but has now ventured into gaining agreement on internal services through the General Agreement on Trade in Services (GATS). WTO claims that nation state protectionist policies pursued during and prior to the 1980s had led to inflation, overexpansion, fiscal deficit and a downturn in economic growth. A 'New Liberalism' emerged, taking corrective action 
by enacting a market-orientated approach, reducing restrictive trade practices and policies, deregulation, and encouraging competition, mainly in the area of trade. More relevant to our present topic is the fact that GATT, which provisionally focused on trade-related issues, began to colonise the services sector space (see the emergence with GATS in 1994 which continues to evolve). The Organisation for Economic Cooperation and Development (OECD) has through both research activities and information dissemination promoted the notion of market liberalisation somewhat in line with the WTO. OCED international and national reports on education and training have placed great emphasis on the human capital approach and also, to an extent, have supported individualisation, particularly in relation to user pays (fees). Human capital investment and employability are identified as positive strategies that can enhance productivity and economic development (see OECD 1999, 2003). The World Bank, on the other hand, has enabled human capital capacity building programmes in developing countries through the provision of strategic loans and finances (see Samoff and Carol 2003). The International Labour Organisation (ILO) has carried out several comparative and country reports relating to employability and labour. The ILO also has a specific department assigned to the field, the Skills and Employability Department. The ILO's research and information dissemination work relating to employment is situated in a global context; one of its major projects is called 'Global Employment Agenda; Employment strategies in support of decent work'. The United Nations Education and Science Committee Organization (UNESCO) has carried out valuable research and active advocacy relating to the right to access education and the positive developmental benefits inherent in education and training programmes, both for the individual and the nation state. Other powerful interest groups related to industry, trade unions and private providers of education and training that have effectively lobbied for a change of policy will be explored. It is the aim of the SRI project team to explore and analyse the major reports produced by these organisations as they relate to employability.

\section{Initial conceptual framework for the research project}

The mode of enquiry utilised for this research will be interpretative, the methodology itself will be firmly located in qualitative research discourse and informed by Guba and Lincoln (1989) Fourth Generation Evaluation. Our enquiry applies evaluation techniques that are more formative than summative. Three layers of analysis are used: claims (positive aspect, agreement, item can be progressed, negotiations finalised); issues (reasonable disagreement, item can progress, negotiations continue); and concerns (negative aspect, strong disagreement, item stopped, contested negotiations). The triangulation process utilised will be confined to data collected from the three discourses - macro, meso, micro (official, non-aligned, insular) - rather than methodological triangulation. The multi-disciplinary nature of the research team adds to the rigour of the triangulation process in terms of ontology and epistemological positioning of the different members. The philosophy underpinning the SRI is based on collegiality and acceptance of difference; it is the difference that creates a healthy tension in the research process. We also utilise Vygotsky's Zones of Proximate Development (ZPD) as a meta-framework to explore the dynamic interaction between 'agency and structure' and to try to identify both social and cultural capital ${ }^{23}$ links (see Figure 1). We will utilise mixed-method research processes such as document analysis, online surveys, interviews and observational studies. Using the collected data, rather than presenting our findings in the orthodox sense instead we will construct 'Learning' based on our interpretation and understanding of the material gathered. This Learning 
will be used to inform the next round of research, of which there will be four main rounds:

1 The first round of research will consist of a systematic literature review, mapping out the concerns, issues and claims expressed by different sectors and actors from macro, meso and micro levels (see Appendix 1, Table 1).

2 The second round of research will involve field research in Ireland comprising a mixed methods approach utilising both qualitative and quantitative research processes; the sampling population will be government agencies, the tertiary education sector, training providers, employer's organisations, trade unions, students and other interested parties (see Appendix 1, Table 2).

3 The third round involves pedagogical considerations and learning and teaching practice plus the development of the Generic Key Skills programme at Level 6 of the NFQ in line with learning outcomes and grid descriptors (see Appendix 1, Table 3).

4 The fourth round will consist of an evaluation of the programme by learners, lecturers and other interested parties. The programmes will be adjusted in accordance with recommendations made as a result of this evaluation. If the evaluation is positive the programme will be mainstreamed and the research team will develop a programme at Level 7 of the NFQ (see Appendix 1, Table 4).

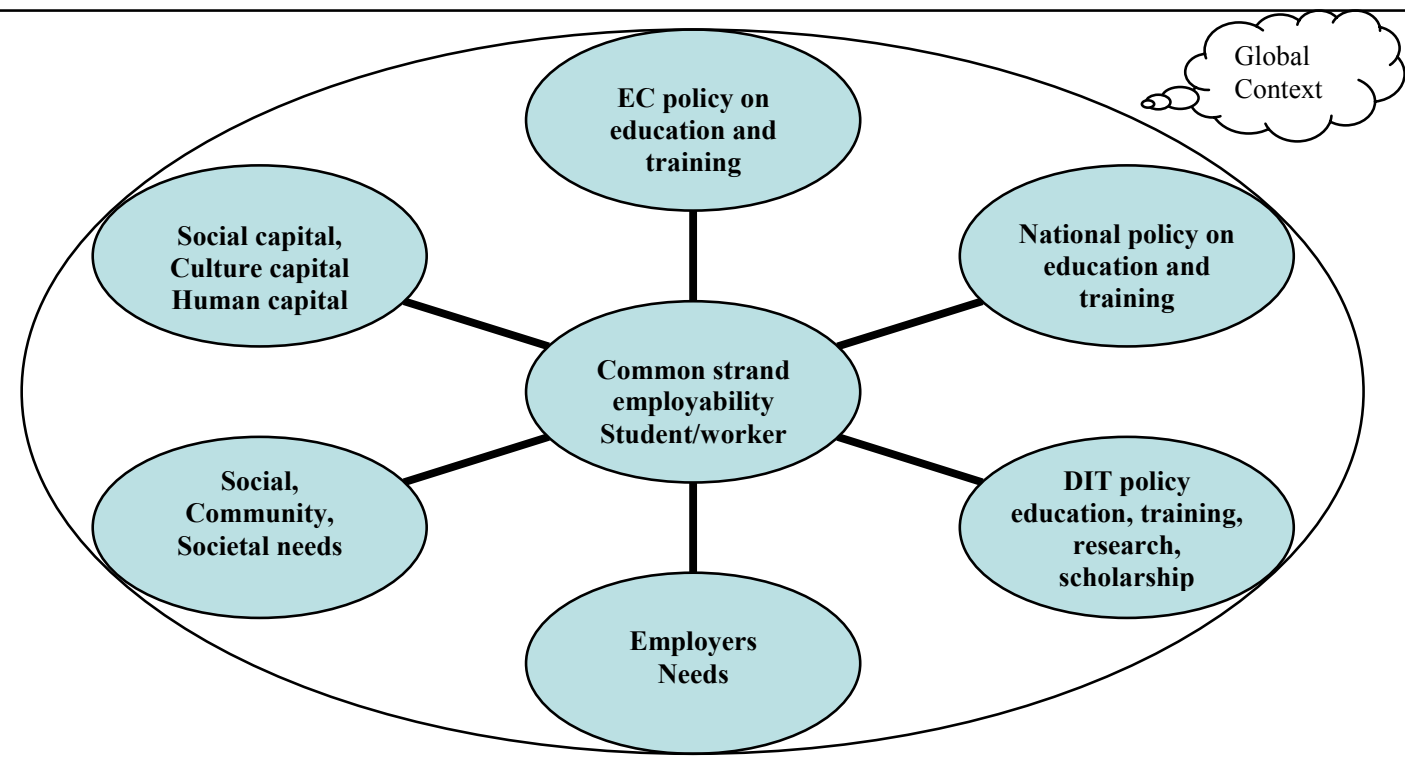

Figure 1 Depiction of structure, agency dynamic with employability as a common strand and the connectivity created by globalisation.

The aim of this project is to produce a programme that will enable the upskilling of the emergent resident workforce in Ireland in key generic skills, thereby making a direct contribution to worker (student) employability and promoting a lifelong learning approach to continuous skills updating. The project objective is to construct and provide a framework of Key Skills Learning modules that offer progression routes 
from Levels 6 to 10 of the NFQ. These modules will incorporate state-of-the-art pedagogical strategies with an emphasis on blended learning. Delivery will be flexible, utilising both online and distance learning technologies and practice, while tutorial support will be provided face to face in either the workplace or an appropriate learning setting. The main premise is to enhance workers' transferable skills capacity thereby enabling increased employability potential.

The project will be co-ordinated by a 'multi-disciplinary' research team, utilising research from several disciplines within the broader episteme of social science. The methodology utilised will be underpinned by a participatory consultation process model. This is somewhat similar to a partnership approach, the main difference being it incorporates more rigour and focus into the research design element of the process. This reduces the risk of distraction or even ambivalence creeping into the emerging research, usually the result of a lack of clarity regarding the research objective or political power play. The initial research into identifying the key skills will be exploratory and utilise a 'mixed method' approach (qualitative data from workshops and focus groups will be used to formulate a online survey; quantitative data from the survey will then be tested in a further serious of workshops and expert peer groups). A 'utilisation-focused evaluation ${ }^{24}$ process will be applied from the start of the project as this enables interventions and modifications to be made in line with emerging evidence. An appropriate code of social science ethical guidelines will be utilised by the project team from the onset of the project.

\section{Dublin Institute of Technology context}

The Dublin Institute of Technology (DIT) is a multi-level HE provider and awarding body. The DIT campus comprises six faculties located in a network of 36 locations in the heart of Dublin, the capital of Ireland. Findings presented in the Institutes Selfevaluation Report for the preliminary stage of the European University Association (EUA) Quality Review of DIT noted that the demographics of the Institute in 2004 consisted of a student body of 19,969, 1001 academic staff and 830 management, support, administration and technical staff. These figures suggest that DIT is one of the largest HE providers in the state. The historical origins of DIT can be traced back to 1887 and the emergence of vocational education. DIT was statutorily established as an autonomous institution by the Irish Government under the DIT Act, 1992. This Act made provisions for the merger of six City of Dublin Vocational Education Committee (CDVEC) Colleges to become an integrated Institute of HE. The Act sets out the Institute's functions, the principal one being to provide vocational and technical education and training for the economic, technological, scientific, commercial, industrial, social and cultural development of the state. In this context the Institute is to provide programmes of study at a range of award levels. Provision is also made for engaging in research, consultancy and development work, either on its own or with other institutions, and to provide services in relation to such work and to exploit the results of this work. DIT's Mission Statement states:

The Institute is a comprehensive higher education institution, fulfilling a national and international role in providing full-time and part-time programmes across the whole spectrum of higher education, supported by research and scholarship in areas reflective of the Institute's mission. It aims to achieve this in an innovative, responsive, caring and flexible learning environment with state-of-the-art facilities and the most advanced technology available. It is committed to providing access to higher education for students of different ages and 
backgrounds, and to achieving quality and excellence in all aspects of its work. This commitment extends to the provision of teaching, research, development and consultancy services for industry and society, with due regard to the technological, commercial, social and cultural needs of the community it serves.

(DIT 2001: 7)

This project is clearly aligned to the DIT Mission Statement and seeks to realise the inherent direction as stated above with regards to access, part-time students, flexible learning models, quality, research and consultancy, and meeting the Institute's societal needs. Further, this project endeavours to identify similarities in policy trends from three difference sources: macro (international), meso (European) and micro (national). From this triangulation process a single strand of enquiry - 'employability' - will be extrapolated and refined. The project will also explore some of the other powerful dynamics at play (see Figure 2).

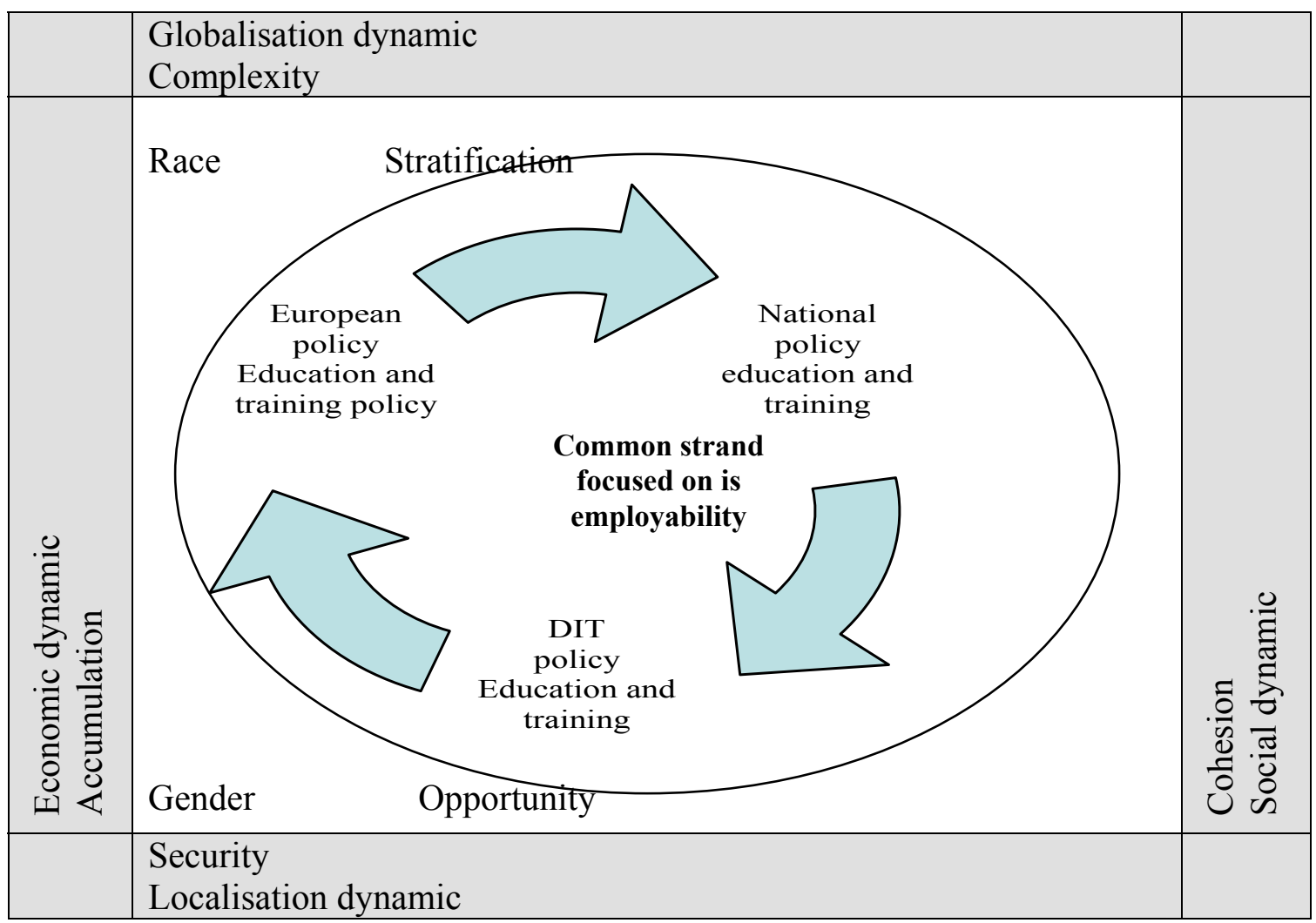

Figure 2 Complex dynamics effecting policy formation on employability

Learning and teaching informed by research is a common strand that flows through these policy levels, and an undercurrent that is emerging is the linkage of education and training to the needs of the labour market. Within the locus of this emerging strand is the notion of workforce capacity and up-skilling to meet the needs and challenges posed by the increasingly competitive employment environment. DIT recognises that the shift from student life to working life presents numerous challenges for all concerned. To advise and assist students during this life-cycle transition DIT provides a professional Careers Service division. Such services are often seen as functionaries of the state, furthering the needs of the economy by advising and guiding students towards jobs that society requires if it is to develop and maintain its economic competitiveness. They are seen as the enablers of human capital theory, working with 
and within HE institutions to ensure an adequate supply and flow of human capital for deployment to meet the economy's needs. This manifests itself operationally as either helping students get their first job or, more basically, getting jobs for students. The DIT Careers Service can and often does do this, but more fundamentally it seeks to place the 'human' at the heart of the human capital debate. Reductionist thinking of viewing humans as sets of skills and competencies meeting economic needs is in itself rather dehumanising. Instead education should focus on the personal and social dimensions of human existence as well as the academic and vocational dimensions.

\section{Employability and career development learning}

The concepts of employability and career development learning offer a unique opportunity to bridge the 'gap' between these dimensions. Employability has both narrow and broad focus definitions differentiated mainly along temporal lines. The first focuses on the quality of immediate employment, generally measured by the First Destinations Research carried out on behalf of the Higher Education Authority (HEA), by all third-level colleges six to eight months after graduation. This rather crude measure does not take into account the time frame often necessary for graduates to make the transition into graduate-level employment. Arriving at the definition of what constitutes a graduate job is in itself hugely problematic. Further, it does not measure whether those jobs taken up under the system do in fact make use of graduate competencies. $^{25}$ The fact that some students take time out to travel or just take shortterm jobs further calls the value of this research into question. A second focus of employability is on 'immediate employability' - whether the student has the competencies and attributes to do a graduate job - the measure of this being 'how well the student (as a new worker) ${ }^{26}$ can hit the ground running'. The third and most expansive focus is on 'sustainable employability'. Yorke and Knight (2006) state that employability 'does not rest when the first graduate job is achieved but needs to be continually renewed to be sustainable'. This, importantly, not only broadens the focus to include a wider range of attributes required to be successful within employment but also includes the attributes required to manage one's career development in ways that will sustain one's employability. This shift crucially moves the debate away from the skills agenda (generic skills; transferable skills; core skills) to something more fundamental: how one manages their career throughout life. The USEM employability model offered by Yorke and Knight (2006) draws on the work of Marzano (1998) who analysed the impact of teaching intervention. He posited that four aspects of human thought operate in all situations:

1 knowledge

2 the cognitive system

3 the metacognitive system

4 the self-system

and suggested that these would be useful organisers for research on instruction.

This model for sustainable employability correlates particularly well with the central aims of careers education. Stanbury defines careers education as:

Those formal processes that empower individuals to identify develop and articulate the skills, qualifications, experiences, attributes and knowledge that will enable them to make an effective 
transition into their chosen futures and manage their careers as lifelong learners, with a realistic and positive attitude.

Watts et al. (2002: 351) state that careers education can act as 'the interface between the individual and society, between self and opportunity, between aspiration and reality'. One of the central aims of careers education is to enable individuals to make and implement career decisions. Law and Watts (1977) developed a conceptual model which has a framework of four components considered to be fundamental to careers education:

- Self-awareness - the ability to identify and articulate motivations, skills and personality as they affect career plans

- Opportunity awareness - knowledge of opportunities available and how to reach them

- Decision making - being able to weigh up personal factors to make a wellinformed and realistic career plan

- Transition learning - understanding how to seek and secure opportunities

This process needs to be dynamic, as an individual will need to relate their understanding of themselves to the opportunities available before arriving at and attempting to implement any career decisions.

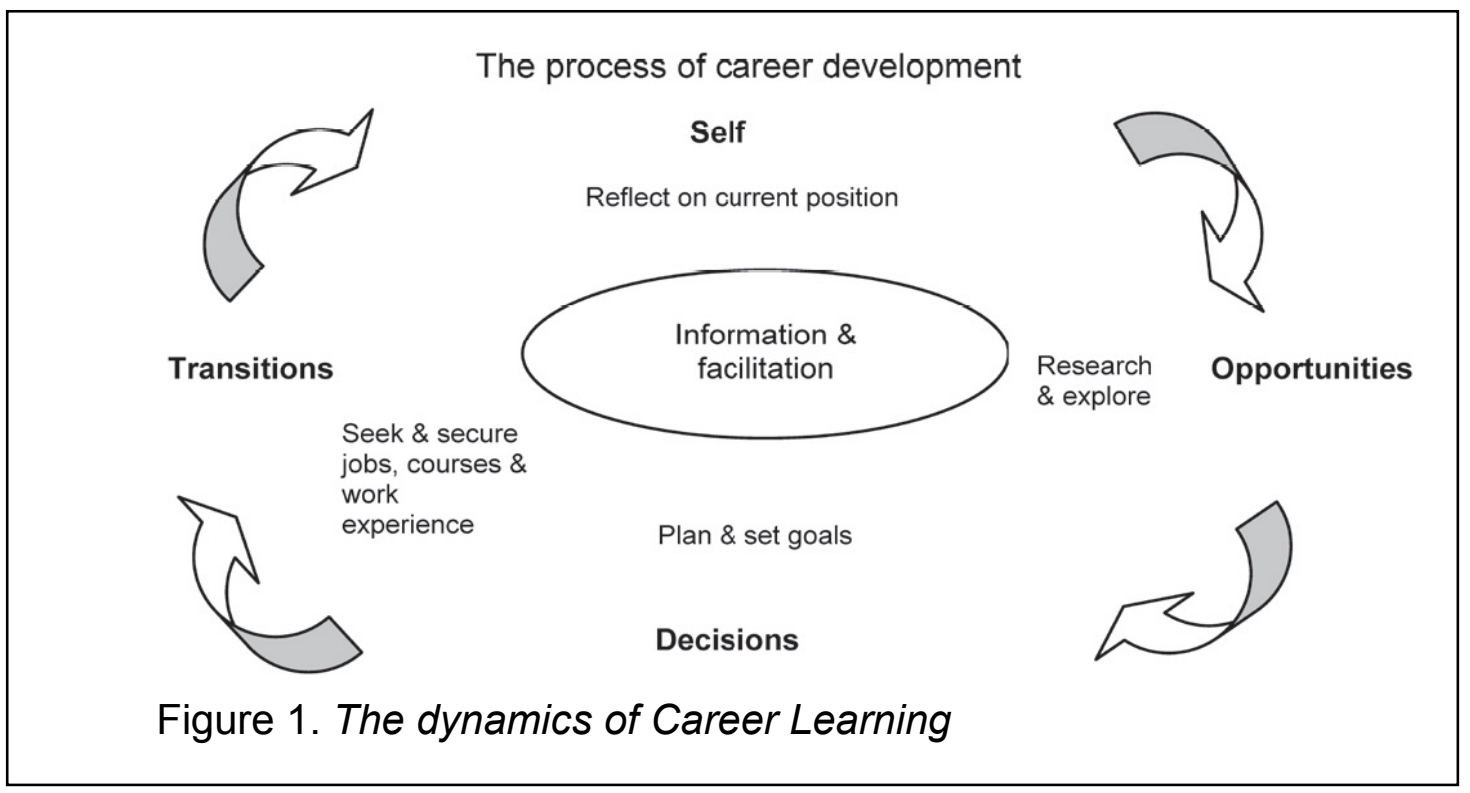

Law, in his 'Post Dots' model, has gone on to focus on the process by which people make career-related decisions, using narrative as a means to draw attention to the influencing factors. Watts (2006) suggests that the skill of managing one's career can be viewed in two ways:

1 as a subset of employability skills;

2 as a related set of meta skills which enable individuals to develop and use the full ranges of their other skills. 
Watts parallels this with Butcher and Harvey's (1998) definition of a meta ability as a 'underlying, learned ability which plays an important role in allowing a wider range of ... knowledge and skills to be used effectively'. He also notes the strong resonances with Yorke and Knight's definition of metacognition as learning how to learn, of reflection in, of and for practice and of a capacity for self-regulation. In fact it is very evident how these concepts align themselves with good academic values. Inherent in the processes of managing one's career is the element of volition, personal control, knowledge of oneself, and knowledge of the factors that influence one's decision making, both personal (e.g. self-efficacy, confidence) and societal (family, community, (sub)culture, labour market trends). Jarvis (2006) outlines the new Career Management Paradigm, which is less about making the right occupational choice that about equipping people with competencies to make the many choices they are faced with continuously in all aspects of their lives. In his Blueprint for Life he identifies core career management competencies and performance indicators at four developmental levels across one's lifespan. The competencies are arranged around three domains:

1 personal management

2 learning and work exploration

3 life/work building.

Jarvis links the failure to engage people in career management to potential economic damage. Human capital theory will be successful if humans at the heart of it remain unfulfilled. Jarvis argues that even with good information and job search skills,

if a person expects to fail again (competency 1), has poor communication and teamwork skills (competency 2), complains about change rather than embracing it (competency 3 ), is not open to learning and innovating (competency 4), and cannot balance life and work effectively (competency 9), they will probably not keep a job long if they are fortunate enough to secure one. Moreover, they will likely not find satisfaction and fulfilment in the job, and their employer is not likely to enjoy high productivity from this employee.

The DIT Careers Service has developed a series of career development programmes for students across the Institute, ranging from bespoke one-day workshops to assessed integrated programmes. The cementing of the partnership approach between careers practitioners and academics is required to ensure all students have access to career development and employability skills. The integration of self-awareness, reflection, personal decision making and action planning should be included in vocationally orientated curricula to ensure deep learning as well as enabling students to take control of their development and progression through learning and work.

\section{DIT and apprenticeship}

DIT delivers both Phases 4 and 6 of the national Standard Based Apprenticeship System (SBAS), catering annually for over 3500 apprentice students. DIT makes provision for 20 out of the 25 nationally designated trade areas. Academic staff in DIT also organise, co-ordinate, develop examination papers and assessment criteria for the National Skills Competition and directly contribute to the Worldskills Competition. Under the 1999 Qualifications (Education and Training) Act, DIT and the Institutes of Technology (IoTs) are described as a secondary provider for the SBAS; FAS, the National Training Authority has the primary contract with the apprentice. The IoT Apprenticeship 
Committee (ITAC) is the body that develops policy and gives DIT and the IoTs a collective voice in the education and training of apprentices. Under the present SBAS apprentice students undertake seven phases of practice and learning: one phase of training in FAS, four phases of Work-Based Learning (WBL) and advanced education and skills development, assessment and student experience occurs during both Phase 4 and 6 in the DIT and the other IoTs. When an apprentice successfully completes examinations at Phase 4 and 6 and have served their time they are awarded a National Craft Certificate (NCC) by the Further Education and Training Awards Council (FETAC). This is a major award placed at Level 6 of the NFQ. SBAS is a dual system of learning and work; specifically, it bridges the gap between formal education and WBL. It shares a lot of the characteristics of vocational education as detailed by UNESCO-UNEVOC (2006), mainly: an educational process involving general education, technology and science, and the acquisition of practical skills, knowledge and understanding relating to occupation, economic and social life. As SBAS provides both practical and related theoretical education it affords an encouraging alternative to pure academic studies. SBAS has been seen as a key method of dealing with the current shortages in the construction industry. A review of the Irish labour market undertaken by FAS in 2002 suggests that there will be a shortage of 11,993 skilled construction workers up to 2006 (FAS 2002a). This figure is not alleviated by the rise in apprenticeship enrolment numbers from 5,000 in the early 1990s (FAS 1998a) to 25,906 in 2002 (FAS 2002b).

Post-NCC, it is apparent, that most apprentices do not progress to higher levels of formal educational attainment. This is recognised in the NDP 2007-2013 which proposes to invest $€ 2.8$ billion in up-skilling people in employment, including new skills for those affected by industrial restructuring and/or job displacement as well as an expansion and enlargement of the apprenticeship system (Irish Times, 27 January 2007). In its final report on 'The demand and supply of engineers and engineering technicians' for the EGFSN, McIver Consulting for Forfás stress that:

it is important that there should be a national framework for the progression from craft level qualifications to higher level qualifications'. \{these qualifications to provide the opportunities to enhance employability and promote new career prospects.

(2003: 113)

EGFSN point out that the importance of apprenticeship has been recognised by the ILO in its World Employment Report and by the OECD (1998) and indicate that the expansion of the apprenticeship system should be reviewed:

In addition the possibility of attracting a greater number of mature students through the introduction of more flexible apprenticeship schemes should be examined. A key issue to consider is the availability of opportunities for apprentices to progress to further and higher education.

(EGFSN 2003: 32)

The OECD had earlier suggested that the apprenticeship style of education and training raised questions regarding the balance between initial and continued lifelong learning. Countries such as Germany and Austria, with their more extensive apprenticeship provision than Ireland, are characterised by strong general and vocational education streams. However, it is suggested that the attractiveness of the vocational route is diminishing, in part, due to the tough economic conditions currently prevailing in Central Europe and high apprenticeship costs. More strikingly, in contrast 
to full-time education the apprenticeship route does not generally leave open the possibility of entering tertiary education at a later date. Taking the Irish perspective this is supported by Clancy and Wall (2000), who indicate that entrants to HE as indicated from the Fathers Socio-Economic grouping, Skilled Manual Worker, was 34 per cent in 1998, up from 28 per cent in 1992; this group includes occupations such as mechanics and electricians. In comparison, nearly 93 per cent and 85 per cent respectively of those from the Higher Professional Socio-Economic grouping entered tertiary education. In its final report for Aimhigher Greater Manchester Partnership, EKOS Consulting identified a participation rate of 26 per cent for a similar Socio-Economic Group and indicated that 19 per cent of those taking the Advanced Modern Apprenticeship may consider undertaking a degree course and that 'if they went on to higher education, then this would represent a significantly higher percentage than the national average' (2004: 9).

A more striking example of the lack of coherent apprentice pathways for progression is provided from the UK by the Cornwall region Aimhigher Peninsula Partnership:

Currently from a cohort of FMA [Foundation Modern Apprenticeship] and AMA [Advanced Modern Apprenticeship] apprentices of almost 21,000 only 60 progressed to higher study; a progress rate of $0.4 \% \ldots$ It is estimated that there are a further 20,000 former apprentices with an L3 qualification who have not progressed to university level study.

(2003: 2)

The NQAI (2003) policy documents details Access, Transfer and Progression procedures, stating:

It is considered that the concept of 'access' should apply to all learners, but particularly to the participation of under-represented learner cohorts such as ... learners in the workplace and adult learners. A more appropriate definition of access for these groups needs to include programme adaptation, or the provision of in-process supports, or even the provision of new variants or formats.

The Framework of Qualifications (2003: 24) develops the basis of these new variants or formats by outlining that they should: facilitate continual and lifelong learning through enhancing the range of learning opportunities and by facilitating change in curricula and delivery methods; and enable the recognition of learning in many non-formal and informal contexts and in new formats. Within DIT the Academic Quality Assurance Committees subgroup report into Access, Transfer and Progression (2004: 2) outlines in the executive summary that access for workplace and adult learners may require programme adaptation, in-house supports and new programme designs. This need to address format changes in apprenticeship and post-apprenticeship learning and employability is a feature of the Key Skills Framework: Enhancing employment within a lifelong learning paradigm. The Academic Quality Assurance Report (DIT 2004: 7) congratulates itself on the ladders of access that allow non-traditional students to enter degree programmes. Many of the pathways suggested as routes for progression lie in a tightly bounded third-level system that is both didactic and prescriptive, Johnson (2003) describing it as the "traditional teaching of a pre-determined academic curriculum'. The draft appendix to its report, the Proposed Model for the Educational Progression for Craftsperson, found post-apprenticeship learners in employment may not be able to avail themselves of full or part-time learning provision due to geographic mobility, self-employment or overtime constraints. Meanwhile, for apprenticeship 
learners the pathways to enhanced employment/learning options, on a full or part-time basis, bear little resemblance to their previous academic experience within the Institute. As Wagner and Childs have previously found 'often universities pride themselves on their access programmes allowing non-traditional students to enter degree programmes, however in very few cases does this translate into the restructure of the course to cater for non-traditional students' (2001: 4).

Johnson agrees, suggesting that employers and prospective students often view the curriculum in $\mathrm{HE}$ as 'too prescriptive, dated, ungrounded, delivered by inaccessible modes and at inaccessible times, and assessed against irrelevant criteria through inappropriate methods' (2000: 1).

The use of strategies such as WBL can be used to overcome the paradigm shift from vocational to HE and to improve avenues of access and progression. Gray (2001) outlines such learning as learning in HE derived from work and includes learning at, for and through work, that is formally linked to the HE curriculum, thus ensuring validity, reliability and authenticity. A learner may undertak 'a taught education programme, the focus of which is the direct application of learning to real work issues and problems, using projects as the primary assessment tool (Gray 2001: 4).

Childs (1997) focuses on the recognition of work as the curriculum that allows for active engagement in workplace enquiry and the production of knowledge that is both 'grounded, shared and developmental'. Reeve and Gallacher (2000: 8) argue that WBL curricula are bounded and regulated in differing ways to traditional curriculum by the nature of the negotiation that establishes the working boundaries. The negotiation involves a tripartite agreement between the learner, the employer and the provider, referred to as the 'educational collective' by Makarenko (1951). Seufert affirms that WBL expressly merges practice, knowledge and theory with experience and that it recognises:

that the workplace offers as many opportunities for learning as the classroom ... work based learning differs from conventional learning in that it involves deep and conscious reflection on actual experiences at the work place. Fundamental to the process is the concept of metacognition.

Learning has been divided by Seufert into single and double loop learning. Single loop learning applies new knowledge to increase the effectiveness of existing operations. Double loop learning leads to new practices and innovation. The need to move from the single loop, competence-based apprenticeship to a meta-competence, learning-to-learn mode needs to be supported by a Key Skills Framework that will provide the supports necessary for the apprentice learner to achieve lifelong learning and employability. In order to create a foundation that will assist apprentice students to progress and create a stimulus for lifelong learning the SRI is carrying out research into developing accessible and flexible programmes for apprentice students while they are at DIT. These programmes would be accredited by DIT in either of the following categories, Special-purpose Awards or Supplemental Awards. These programmes could be offered under the remit of Continuous Professional Development (CPD), each programme would be accredited and the apprentice student could build up ECTS. Also within the modularisation philosophy, broader cross-faculty programmes could be offered in the fields of applied arts, science and technology. These programmes would 
consist of both taught and self-directed learning; taught components would consist of between six and seven two-hour sessions, while self-directed learning work would occur during project work. Assessment could be based on portfolio development. These programmes would be considered as introductory or foundation level, therefore the workload would be light. The primary emphasis would be to deposit the seed for lifelong learning and opportunities for progression pathways. The main drive of these programmes would be developmental and capacity building, in essence preparing the apprentice student to engage in FE within the Lifelong Learning paradigm.

\section{Conclusion}

This brief conceptual paper, which is a work in progress, outlines our research subject area and the framework, methodology and processes developed by the multidisciplinary research team. We show that employability is a complex construct which has different inherent meanings to diverse interested parties. Our intent is to refocus attention and the potential of employability back onto the student/worker. Within the DIT context we are endeavouring to construct learning from our analysis of macro, meso and micro discourses and turn this learning into a real-world programme. The programme will be underpinned by pedagogy which is informed by research. Our intention is to make provision accessible and enable the up-skilling of workers and students in key skills areas relating to the conceptual construct of employability. The project team is open to receiving critical commentary on this project and development collaboration with other researcher carrying out similar research projects. The research team claim that this project represents an opportunity to holistically address the development of employability and career management skills within vocational programmes in DIT.

\section{Bibliography}

Aimhigher Peninsula Partnership (2004) Increasing Advanced Apprenticeship Progression onto Higher Education - Bridging the Gap. Available online at http://www.uwe.ac.uk/widen/docs/workhigher.doc (accessed 14 May 2005).

Anderson, L. (1998) 'Evaluation as a Strategy of Modernisation', New Directions for Evaluation 77 (Spring): 39-53.

Apple, M. (2001) Educating the Right Way, Markets, Standards, God and Inequality, New York and London: Routledge/Falmer Press.

Apple, M. (2003) Official Knowledge, New York and London: Routledge/Falmer Press.

Aronson, E., Wilson, T.D. and Arkert, R.M. (1994) Social Psychology, New York: Harper Collins Publishers.

Ball, S. (2004) The RoutledgeFalmer Reader in Sociology of Education. London and New York: Routledge.

Barlas, Y. and Yasarcan, H. (2006) 'Goal Setting, Evaluation, Learning and Revision: A Dynamic Modelling Approach’, Evaluation and Program Planning (29): 79-87. 
Barlow, A. (2005) 'Evaluation: What is it for Really. A Framework for Examining Issues of Evaluation Purpose and Use', Evaluation Journal of Australasia, 5 (1): 11-17.

Barnett, R. (1997) Higher Education: A Critical Business, Milton Keynes: The Society for Research into Higher Education, Open University.

Barnett, R. (1999) Realising the University in an Age of Supercomplexity, Philadelphia: Open University Press.

Barnett, R. (ed.) (2005) Reshaping the University: New Relationships Between Research, Scholarship and Teaching, Maidenhead: McGraw-Hill/Open University Press.

Beck, J. (1999) 'Makeover or Takeover? The Strange Death of Educational Autonomy in Neo-Liberal England', British Journal of Sociology of Education, 20 (2): 223-238.

Becker, G. (1993) Human Capital, A Theoretical and Empirical Analysis with Special Reference to Education, 3rd edn, Chicago: University of Chicago Press.

Bernstein, B. (2000) Pedagogy, Symbolic Control and Identity, Plymouth: Rowman \& Littlefield.

Bickman, L. (1997) 'Evaluating Evaluation: Where do we go from here?' Evaluation Practice, 18 (1): 1-16.

Bills, D. (2004) The Sociology of Education and Work, Boston: Blackwell Publishing.

Blaikie, N. (1993) Approaches to Social Enquiry, London: Polity Press.

Bonal, X. (2003) 'The Neoliberal Educational Agenda and the Legitimation Crisis: Old and New State Strategies', British Journal of Sociology of Education, 24 (3): 51595175 .

Bourdieu, P. (1984) Homo Academicus, London: Polity Press.

Bourdieu, P. (1998) The State Nobility, London: Polity Press.

Bourdieu, P. and Passeron, J. (2000) Reproduction in Education, Society and Culture, 2nd edn, London: Sage.

Braverman, H. (1998) Labor and Monopoly Capital, The Degradation of Work in the Twentieth Century, 25th anniversary edn, New York: Monthly Review Press.

Brehony, K. and Deem, R. (2005) 'Challenging the Post-Fordist/Flexible Organisation Thesis: The Case of Reformed Educational Organisations', British Journal of Sociology of Education, 26 (3) (July): 395-414.

Brenda, L. and Enhancing Student Employability Co-ordination Team (ESECT) (2006) Employability and Work-based Learning, York: The Higher Education Academy. 
Brennan, J., Kogan, M. and Teichler, U. (1996) 'Higher Education and Work', British Journal of Sociology of Education, 11 (1): 65-85.

Brown, P. (1990) 'The "Third Wave": Education and the Ideology of Parentocracy', British Journal of Sociology of Education, 11 (1): 65-85.

Brown, P., Hesketh, A. and Williams, S. (2003) 'Employability in a Knowledge-driven Economy 1', Journal of Education and Work, 16 (2).

Burke, V., Jones, I. and Doherty, M. (2005) 'Analysing Student Perceptions of Transferable Skills Via Undergraduate Degree Programmes’, Active Learning in Higher Education, 6 (2): 132-144.

Carr, W. (2005a) Philosophy of Education. The Routledge Reader, London and New York: Routledge.

Carr, W. (2005b) The RoutledgeFalmer Reader in Philosophy of Education, London: Routledge.

Carr, W. and Kemmis, S. (2000) Becoming Critical. Education, Knowledge and Action Research, London: Falmer Press.

CEDEFOP (1994) The Present Situation and the Future Prospects of Apprenticeship Training in the European Union: Contribution for the FORCE Seminar on 30.4.94 with Participants from Northern Ireland and the Republic of Ireland, Berlin: CEDEFOP.

CEDEFOP (1999) Ireland. Review of Labour Market Entry Programmes. Berlin: CEDEFOP.

CEDEFOP (2002) Ireland: Educational Progression for Craftspersons, Berlin: CEDEFOP. Also available online at http://www2.trainingvillage.gr (accessed 3 December 2006).

Childs, M. (ed.) (1997) A Slight Breathing Space. A Guide to Working with Micro and Small to Medium Business Enterprises for Adult Educators and the VET Sector, Penrith South DC: University of Western Sydney Nepean.

Clancy, P. and Wall, J. (2000) Social Background of Higher Education Entrants, Dublin: Higher Education Authority.

Clancy P. et al. (1997) Irish Society: A Sociological Perspective, Dublin: The Institute of Public Administration.

Cohen, L., Manion, L. and Morrison, K. (2004) Research Methods in Education, 5th edn, London: Routledge/Falmer/Taylor Francis Group.

Commission of the European Communities (2005) Communication from the Commission, Modernising Education and Training: Vital Contribution to Prosperity and Social Cohesion in Europe, Brussels, 30/11/2005, com(2005)549 final/2. 
Coolahan, J. (2004) Higher Education in Ireland, Country Background Report, Government Publications, Molesworth St, Dublin 2: Stationery Office.

Creswell, J. (1994) Research Design, Qualitative and Quantitative Approaches, London: Sage.

Creswell, J.W. (1998) Qualitative Inquiry and Research Design, Choosing Among Five Traditions, int. edn, London: Sage.

Creswell, J.W. (2005) Educational Research, Planning, Conducting, Evaluating, Quantitative and Qualitative Research, 2nd edn, int. edn, Upper Sadle River, NJ: Pearson Merrill/Prentice Hall.

Crossley, N. (2005) Key Concepts in Critical Social Theory, London: Sage.

Crotty, M. (1998) The Foundations of Social Research, Meaning and Perspective in the Research Process, London: Sage.

Darder, A., Baltodano, M. and Torres, R. (2003) The Critical Pedagogy Reader, New York and London: Routledge/Falmer Press.

Dearing Report (1997) Higher Education in the Learning Society, London: HMSO.

Denzin, N. and Lincoln, Y. (2000) Handbook of Qualitative Research, 2nd edn, London: Sage.

Department of Education and Science (1995) Charting our Education Future: White Paper on Education, Government Publications, Molesworth St, Dublin 2: Stationery Office.

Department of Education and Science (1999) The Qualifications. (Education and Training) Act, Government Publications, Molesworth St, Dublin 2: Stationery Office.

Department of Education and Science (2005a) Scientific and Technological Education (Investment) Fund: Annual Report. Available online at

http://www.education.ie/servlet/blobservlet/ste_fund_ar2005.pdf (accessed 5 October 2007).

Department of Education and Science (2005b) Irish Progress Report 'Modernisation of Education and Training 2010', Government Publications, Molesworth St, Dublin 2: Stationery Office.

Dewey, J. (1997) Experience and Education, New York: Touchstone.

DIT (2001) Strategic Plan: Mission Statement, 2001-2015, Dublin: DIT, p. 7.

DIT (2004) Academic Quality Assurance Committees Sub-Group Report into Access, Transfer and Progression, Dublin: DIT. 
EGFSN (2003) Benchmarking Education and Training for Economic Development in Ireland, Dublin: Forfás.

EGFSN (2004) OECD Review of Higher Education in Ireland. Higher Education System and Responding to Ireland's Skill Needs, Dublin: Forfás.

EGFSN (2005) Skills Needs of the Irish Economy, the Role of Migration, Dublin: Forfás.

EKOS Consulting (2004) Progression Routes into Higher Education on Greater Merseyside, Final Report for Aimhigher Greater Merseyside, Liverpool.

Enterprise Strategy Group Report (2004) Ahead of the Curve, Ireland's Place in the Global Economy, Government Publications, Molesworth St, Dublin 2: Stationery Office.

ESECT/LTSN Generic Centre 'Learning and Employability' Series, York: The Higher Education Academy.

Etzkowitz, H. and Leydesdroff, L. (2001) Universities and the Global Knowledge Economy: A Triple Helix Of University-Industry-Government Relations, New York and London: Continuum.

EU Commission (2006) Lifelong Learning: A New Education and Training Programme to Build the Knowledge Society, Brussels, 25 Ocotber 2006

EUA (2004) Quality Review Guidelines, and Review Visits. Available online at www.eua.com (accessed 10 November 2004).

Evans, L. (2002) Reflective Practice in Education Research, New York and London: Continuum.

FAS (1998a) Apprenticeship Activity 1996-1997, Dublin: FAS.

FAS (1998b) Annual Report to 31 December 1997, Dublin: FAS.

FAS (2002a) Standards Based System - December 2001, Dublin: FAS.

FAS (2002b) Irish Labour Market Review, Dublin: FAS.

Fetterman, D.M. (2001) Foundations of Empowerment Evaluation, Thousand Oaks, CA and London: Sage.

Field, J. and O'Dubhchair, M. (2001) 'Recreating Apprenticeship: Lessons from the Irish Standards Based Model', Journal of Vocational Education and Training, 53: 247261.

Fisher, S. (2006) 'Dissertation Literature Reviews and Doctoral Students - Evoking Creativity or Compliant banality', unpublished paper. Available online at sandra.fisher@dit.ie. 
Forfás (2003) The Demand and Supply of Engineers and Engineering Technicians, $A$ Study for the Expert Group on Future Skills Needs by McIver Consulting, Dublin: Forfás. Also available online at http://www.forfas.ie/futureskills/reports/futureskills3/12_info_tech.htm (accessed 10 January 2006).

Forrier, A. and Sels, L. (2003) 'Temporary Employment and Employability: Training Opportunities and Efforts of Temporary and Permanent Employees in Belgium', Work, Employment and Society, 17 (4): 641-666.

Freire, P. (1996) Pedagogy of the Oppressed, new int. edn, London: Penguin.

Fugate, M., Kinicki, A. and Ashforth, B. (2004) 'Employability: A Psycho-social Construct, Its Dimensions, and Applications', Journal of Vocational Behaviour 65: 1438 .

Fulop, L. and Linstead, S. (1999) Management, A Critical Text, London: Macmillan Press.

Gadotti, M. (1996) Pedagogy of Praxis: A Dialectical Philosophy of Education, New York: State University of New York Press.

Garavan, T. et al. (2002) 'Human Resource Development and Workplace Learning: Emerging Theoretical Perspectives and Organisational Practices', Journal of European Industrial Training, 26 (2-4): 60-71.

Gardner, D. (1977) 'Five Evaluation Frameworks: Implications for Decision Making in Higher Education', Journal of Higher Education, 48 (5): 571-593.

Gibbons, M. et al. (2005) The New Production of Knowledge. The Dynamics of Science and Research in Comtemporary Societies, London: Sage.

Giddens, A. (1992) Capitalism and Modern Social Theory, Cambridge: Cambridge University Press.

Giddens, A. (1995) Human Societies, A Reader, London: Polity Press.

Giddens, A. (2004a) Sociology, 4th edn, London: Polity Press.

Giddens, A. (2004b) The Constitution of Society, London: Polity Press.

Goleman, D. (1999) Working with Emotional Intelligence, London: Bloomsbury.

Gray, D. (2001) A Briefing on Work-based Learning, York: LTSN Generic Centre.

Grint, K. (2005) The Sociology of Work, 3rd edn, London: Polity Press. 
Guba, E. and Lincoln, Y. (1989) Fourth Generation Evaluation: Claims Relate to Positive Aspects, Concerns Relate to Negative Aspects and Issues to Mid ground Aspects, London: Sage.

Guba, E. and Lincoln, Y. (2001) Guidelines and Checklist for Constructivist. (AKA Fourth Generation), evaluation paper available, Kalamazoo, MI: Evaluation Centre. Available online at http://www.wmich.edu/evalctr/checklists/constructivisteval.htm (accessed 30 May 2005).

Guile, D. and Young, M. (2001) Knowledge Power and Learning. Apprenticeship as a Conceptual Basis for a Social Theory of Learning, London: Paul Chapman.

Gunnigle, P., McMahon, G. and Fitzgerald, G. (1999) Industrial Relations in Ireland, Theory and Practice, 2nd edn, Dublin: Gill and MacMillan.

Halsay, A. et al. (2002) Education: Culture, Economy and Society, Oxford: Oxford University Press.

Halstead, J. (1996) 'Liberal Values and Liberal Education', in Halstead, J. and Taylor, M. (eds), Values in Education and Education in Values, London: Falmer.

Handy, C. (1993) Understanding Organisations, London: Penguin.

Hardy, M. and Bryman, A. (2004) Handbook of Data Analysis, London: Sage.

Hart, C. (2005) Doing a Literature Review: Releasing the Social Science Research Imagination, London: Sage.

Harvey, L. (2000) 'New Realities: The Relationship Between Higher Education and Employment', Education and Management, 6: 3-17.

Harvey, L. (2001) 'Defining and Measuring Employability', Quality in Higher Education, 7 (2).

Hermann, C. (2005) Neoliberalism in the European Union. Thematic paper: Project: Dynamics of National Employment Models (DYNAMO) Work Package 1: Development of a Theoretical Framework for Comparative and Dynamic Analysis of National Models. Thematic Area: Impact of Political/Governance Change on National Models, Vienna: Working Life Research Centre

Higher Education Authority (1999) Recommendation of the Higher Education Authority to Government in accordance with the terms of Section 9 of the Universities Act, 1997 concerning the Application by DIT for establishment as a University, Dublin, Higher Education Authority.

Hillage, J. and Pollard, E. (1998) Employability: Developing a Framework for Policy Analysis, DfEE Research Briefing No. 85. London: DfEE.

Hirst, P. and White, P. (1998) Philosophy of Education: Major Themes in the Analytic Tradition; Volume III Society and Education, London and New York: Routledge. 
House, E. R. (2006) ‘Democracy and Evaluation’, Evaluation, 12 (1): 119-127.

Hughes, J. and Sharrock, W. (1997) The Philosophy of Social Research, 3rd edn, London and New York: Longmans.

Illich, I. (2002) Deschooling Society, London and New York: Marion Boyars Publishers.

Jarvis, P.S. (2006) 'Career Information: Essential Yet Insufficient', available online at http://www.igc.ie/download/1/Phil\%20Jarvis\%20Galway\%20Paper.doc (accessed 5 October 2007).

Johnson, D. (2000) 'The Use of Learning Theories in the Design of a Work-Based Learning Course at Masters Level', Innovations in Education and Training International, 37 (2): 129-133.

Kivinen, O. and Ahola, S. (1999) 'Higher Education as Human Risk Capital: Reflections on Changing Labour Markets', Higher Education, 38 (2).

Knight, P. (2001) 'Editorial: Employability and Quality', Quality in Higher Education, 7 (2).

Lauder, H. et al. (2006) Education, Globalization and Social Change. Oxford: Oxford University Press.

Law, B. (1999) New DOTS: Career Learning for the Contemporary World, NICEC briefing, Cambridge: CRAC. Available online at http://www.hihohiho.com/memory/cafnewdots.pdf (accessed 5 October 2007).

Law, B.A. and Watts, A.G. (1977) Schools, Careers and Community, London: Church Information Office.

Lawson, T., Harrison, J. and Cavendish, S. (2004) Individual Action Planning: A Case of Self Surveillance, British Journal of Sociology of Education, 25 (1): 81-94.

Lynch, K. (1994) An Analysis of the Differences Between Education Policies based on Principals of Equity, Equality of Opportunity and Egalitarianism. Equality of Opportunity in Third Level Education in Ireland, Dublin: National Unit for Equal Opportunities at Third Level.

Lynch, K. (2005) 'Achieving Equity of Access to Higher Education: Setting An Agenda For Action in Ireland', Proceedings of the HEA Conference (6-7 December 2004 Kilkenny), Dublin: HEA.

Lynch R. (2006a) 'Employability and the "Responsibilized Self”, paper presented at the Society for Research into Higher Education (SRHE) conference, Brighton, UK.

Lynch, K. (2006b) 'Neo-Liberalism and Marketisation: The Implication for Higher Education', European Education Research Journal, 5 (1). 
Mag Cuill, D. (2003) 'Mature Students: An Examination of DIT's Policy and Practice', Level 1. Full text available online at http://level3.dit.ie/pdf/issue1_magcuill.pdf (accessed 5 October 2007).

Makarenko, A. (1951) The Road to Life. An Epic of Education, Moscow: Progress Publishers.

McMillan, N. (2000) Prometheus's Fire: A History of Scientific and Technological Education in Ireland, 1st edn, Kilkenny: Tyndall Publications.

Morley, L. (2001) 'Producing New Workers: Quality, Equality and Employability in Higher Education', Quality in Higher Education, 7 (2).

Naidoo, R. (2003) 'Repositioning Higher Education as a Global Commodity: Opportunities and Challenges for the Future Sociology of Education Work', British Journal of Sociology of Education, 24 (2): 249-259.

National Competitiveness Council (2000) Annual Competitiveness Report 2000, Government Publications, Molesworth St, Dublin 2: Stationery Office.

National Competitiveness Council (2005) Annual Report. Available online at http://www.competitiveness.ie.

National Economic and Social Forum (2003) Early School Leavers Forum Report No.24, Dublin: National Economic and Social Forum.

National University of Ireland, Galway (2000) Contemporary Issues/Society, Galway. NUIG.

NDP 2000-2006, Government Publications, Molesworth St, Dublin 2: Stationery Office.

NDP 2007-2013, Government Publications, Molesworth St, Dublin 2: Stationery Office.

NQAI (2003) Framework of Qualifications, Dublin: NQAI.

NQAI (2004) National Framework of Qualifications-An Overview, Dublin: NQAI.

O'Connor and Harvey, N. (2001) 'Apprenticeship Training in Ireland: From Timeserved to Standards-based: Potential and Limitations for the Construction Industry, Journal of European Industrial Training, 25: 332-342.

Oakley A. (2004) The Researchers Agenda for Evidence, Evaluation Research in Education, 18 (1 \& 2): 12-27.

OECD (1994) Apprenticeship: Which Way Forward, Paris: OECD.

OECD (1998a) Education at a Glance, Paris: OECD Indicators. 
OECD (1998b) Opening Pathways from Education to Work, Paris: OECD Observer No.214, Paris. Available online at http://www1.oecd.org/publications/observer/214/article1_eng.htm (accessed 11 May 2005).

OECD (1999) Human Capital Investment, International Comparison, Paris: OECD.

OECD (2004a) Review of Higher Education in Ireland, Paris: OECD.

OECD (2004b) Review of National Polices for Education: Review of Higher Education in Ireland Examiners' Report, Government Publications, Molesworth St, Dublin 2: Stationery Office.

OECD (2005a) Modernising Government, The Way Forward, Paris: OECD.

OECD (2005b) Moving Mountains, How Can Qualifications Systems Promote Lifelong Learning? preliminary edn, Paris: OECD.

OECD (2006) Market Failures and the Under Provision of Training, for Details Relating to Under Provision and Funding and Human Capital Obsolesces, Paris: OECD

Oliver S. et al. (2005) 'An Emerging Framework for Including Different Types of Evidence in Systematic Reviews for Public Policy', Evaluation, 11 (4): 428-446.

Patton, M.Q. (1997) Utilisation Evaluation, The New Century Text, 3rd edn, Thousand Oaks, CA: Sage.

Pawson, R. and Tilley, N. (2001) Realistic Evaluation, Thousand Oaks, CA: Sage.

Pring, R. (1996) 'Values and Education Policy', in Halstead, J. and Taylor, M. (eds), Values in Education and Education in Values, London: Falmer Press.

Qualifications (Education and Training) Act, 1999, available from Stationery Office, Government Publications, Molesworth St., Dublin 2, Ireland.

Reeve, F. and Gallacher, J. (2000) Implementing Work-based Learning in Higher Education: Exploring Control and Negotiation in the Curriculum, UTS Research Centre Vocational Educational and Training Working Knowledge: Productive Learning at Work. Conference Proceedings 10-13 December 2000, University of Technology Sydney New South Wales, Australia.

Ritzer, G. (1996) Sociological Theory, 4th edn, int. edn, New York and London: McGraw-Hill.

Ritzer, G. (2006) McDonaldisation, The Reader, 2nd edn, Thousand Oaks, CA and London: Pine Forge Press. 
Robson, C. (2002) Real World Research: A Resource for Social Scientists and Practitioner-Researchers, Oxford: Blackwell.

Robson, M. (1994) Facilitating, Aldershot: Gower.

Rohmann, C. (2000) The Dictionary of Important Ideas and Thinkers, London: Arrow.

Rossi, P.H., Freeman, H.E. and Lipsey, M.W. (1999) Evaluation, A Systematic Approach, 6th edn, Thousand Oaks, CA: Sage.

Rowland, S. (2006) 'Interdisciplinary Collaboration: A Site for Contestation', Paper presented at the Society for Research into Higher Education. (SRHE) conference, Brighton, UK.

Sabel, C. (1982) Work and Politics: The Division of Labour in Industry, Cambridge: Cambridge University Press.

Sanders, J. and de Grip, A. (2003) Training, Task Flexibility and Low-Skilled Workers' Employability, Research Centre for Education and the Labour Market, Faculty of Economics and Business Administration, Maastricht University.

Sarantakos, S. (1998) Social Research, 2nd edn, London: Macmillan.

Sawchuk, P. (2003) 'The Unionization Effect among Adult Computer Learners', British Journal of Sociology of Education, 24 (5): 637-648.

School of Manufacturing Engineering (2001) Strategic Plan, Dublin: DIT.

Sennett, R. (2006) The Culture of the New Capitalism, London and New Haven, CT: Yale University Press.

Seufert, S. (2000) 'Work-Based Learning and Knowledge Management: An Integrated Concept of Organizational Learning', Proceedings of the 8th European Conference on Information Systems, Trends in Information and Communication Systems for the 21st Century, ECIS 2000, Vienna, Austria, 3-5 July. Available online at BibTeX http://www.scil.ch/seufert/publications-en.html (accessed 1 October 2005; quote viewed 30 January 2007).

Shah, A., Pell, K. and Brooke, P. (2004) 'Beyond First Destinations Graduate Employability Survey', Active Learning in Higher Education', 5 (1): 9-26.

Sheldon, P. and Thornthwaite, L. (2005) 'Employability Skills and Vocational Education and Training Policy in Australia: An Analysis of Employer Association Agendas', Asia Pacific Journal of Human Resources, 43 (3).

Singh, P. (2002) 'Pedagogising Knowledge: Bernstein's Theory of Pedagogic Device', Journal of Sociology of Education, 23 (4): 571-582. 
Skilbeck, M. (2001) The University Challenged, A Review of International Trends and Issues with Particular Reference to Ireland, Higher Education Authority, Government Publications, Molesworth St, Dublin 2: Stationery Office.

Skilbeck, M. (2003) Towards an Integrated System of Tertiary Education: A Discussion Paper, Dublin: DIT.

Skilbeck, M. and Connell, H. (2000) Access and Equity in Higher Education. An International Perspective on Issues and Strategies, Higher Education Authority, Government Publications, Molesworth St, Dublin 2: Stationery Office.

Sklair, L. (2001) The Transnational Capitalist Class, London: Blackwell.

Stufflebeam, D.L., Madaus, G.F. and Kellaghan, T. (2000) Evaluation Models, Viewpoints on Educational and Human Services, 2nd edn, Boston and London: Kluwer Academic Publishers.

Stake, R. (1995) The Art of Case Research. Thousand Oaks, CA: Sage.

Stame, N. (2003) 'Evaluation and Policy Context: The European Experience', Evaluation Journal of Australasia, 3 (2): 36-43.

Stame, N. (2006) 'Governance, Democracy and Evaluation’, Evaluation, 12 (1): 7-16.

Strategy for Science Technology and Innovation 2006-2013, Government Publications, Molesworth St, Dublin 2: Stationery Office.

Sustaining Progress (2003) Social Partnership Agreement 2003-2005, Government Publications, Molesworth St, Dublin 2: Stationery Office.

Sustaining Progress (2004) Progress Report on Special Initiatives, Department of the Taoiseach, Government Publications, Molesworth St, Dublin 2: Stationery Office.

Task Force on the Physical Sciences (2003) Report and Recommendations. Available online at http://www.sciencetaskforce.ie/report (accessed 5 May 2005).

Taylor, J. (2006) 'Managing the Unmanageable: The Management of Research in Research-intensive Universities', Higher Education Management Policy, 18 (2): 1-24.

Tiernan, S., Morley, M. and Foley, E. (2001) Modern Management, Theory and Practice for Irish Students, 2nd edn, Dublin: Gill and McMillan.

Towards 2016 Ten-year Framework Social Partnership Agreement 2006-2015, available from Stationery Office, Government Publications, Molesworth St., Dublin 2, Ireland.

UK Department of Education and Skills (2005) Key Skills Policy and Practice, Your Questions Answered, London: UK Department of Education and Skills. 
Universities Act (1997) Government Publications, Molesworth St, Dublin 2: Stationery Office.

UNESCO-UNEVOC (2006) 'Orienting Technical and Vocational Education and Training for Sustainable Development', Discussion Paper Series 1, Bonn: UNESCOUNEVOC.

Wagner, R. and Childs, M. (2001) 'Workbased Learning as Critical Social Pedagogy', Australian Journal of Adult Learning, 41 (3): 314-334.

Watts, A.G. (2006) Career Development Learning and Employability, Learning and Employability Series 2 (5), York: The Higher Education Academy.

Watts, A.G. et al. (2002) Rethinking Careers Education and Guidance, New York: Routledge.

Weiss C. (1998) Evaluation, 2nd edn, Upper Saddle River, NJ: Prentice Hall.

Winterton, J., Delamare Le Deist, F., Stringfellow, E. (2006) Typology of Knowledge, Skills and Competences: Clarification of the Concept Prototype, Report for Centre of European Research on Employment and Human Resources, Toulouse. Available online at

http://www.cpi.si/files/userfiles/Datoteke/Novice/EKO/Prototype typology_CEDEFOP 26 January 2005\%201\%20.pdf (accessed 5 October 2007).

Yin, R. (1994) Case Study Research, Design and Methods, 2nd edn, int. edn, Thousand Oaks, CA: Sage.

Yorke, M. (2006) Employability in Higher Education: What It Is - What It Is Not, Enhancing Student Employability Co-ordination Team. (ESECT), York: The Higher Education Academy.

Yorke, M. and Knight, P.T. (2006) Embedding Employability into the Curriculum, Enhancing Student Employability Co-ordination Team. (ESECT), York: The Higher Education Academy.

Young, M. (2005) InFocus Programme on Skills, Knowledge and Employability, Skills Working Paper No. 22 , International Labour Organisation.

Zgaga, P. (2003) 'Reforming the Universities of South East Europe in View of the Bologna Process', Higher Education in Europe, XXVIII (3): 251-258.

Zuber-Skerritt, O. and Perry, C. (2002) 'Action Research within Organisations and University Thesis Writing', Journal of the Learning Organisation, 9 (4): 171-179. 
Appendix 1

Table 1

\begin{tabular}{|l|l|l|l|l|}
\hline \multicolumn{5}{|c|}{ Research conceptual framework round 1 review (Macro, Meso, Micro) } \\
\hline & $\begin{array}{l}\text { Official } \\
\text { discourse }\end{array}$ & $\begin{array}{l}\text { Non aligned } \\
\text { discourse }\end{array}$ & $\begin{array}{l}\text { Insular } \\
\text { discourse }\end{array}$ & The learning \\
\hline Issues & & & & \\
\hline Concerns & & & & \\
\hline Claims & & & \\
\hline
\end{tabular}

Table 2

\begin{tabular}{|l|l|l|l|l|}
\hline \multicolumn{5}{|c|}{ Research conceptual framework round 2, field work (Micro) } \\
\hline & $\begin{array}{l}\text { Official } \\
\text { discourse }\end{array}$ & $\begin{array}{l}\text { Non-aligned } \\
\text { discourse }\end{array}$ & $\begin{array}{l}\text { Insular } \\
\text { discourse }\end{array}$ & The learning \\
\hline Issues & & & & \\
\hline Concerns & & & & \\
\hline Claims & & & & \\
\hline
\end{tabular}

Table 3

\begin{tabular}{|l|l|l|l|l|}
\hline \multicolumn{5}{|c|}{ Research conceptual framework round 3, test module Level 6 NFQ } \\
\hline $\begin{array}{l}\text { Learning } \\
\text { outcomes }\end{array}$ & Description & Description & Description & Description \\
\hline $\begin{array}{l}\text { Knowledge } \\
\text { (breadth) }\end{array}$ & & & & \\
\hline $\begin{array}{l}\text { Knowledge } \\
\text { (Kind) }\end{array}$ & & & & \\
\hline $\begin{array}{l}\text { Know-how \& } \\
\text { skill (Range) }\end{array}$ & & & & \\
\hline $\begin{array}{l}\text { Know-how \& } \\
\text { skill (Selectivity) }\end{array}$ & & & & \\
\hline $\begin{array}{l}\text { Competence } \\
\text { (Context) }\end{array}$ & & & & \\
\hline $\begin{array}{l}\text { Competence } \\
\text { (Role) }\end{array}$ & & & & \\
\hline $\begin{array}{l}\text { Competence } \\
\text { (Learning to } \\
\text { Learn) }\end{array}$ & & & & \\
\hline $\begin{array}{l}\text { Competence } \\
\text { (Insight) }\end{array}$ & & & & \\
\hline
\end{tabular}

Table 4

\begin{tabular}{|l|l|l|l|l|}
\hline \multicolumn{5}{|c|}{ Research conceptual framework round 4 Programme Evaluation } \\
\hline & Learner & Lecturer & Employer & The learning \\
\hline Issues & & & & \\
\hline Concerns & & & & \\
\hline Claims & & & \\
\hline
\end{tabular}




\section{Appendix 2}

Extract; Employment and Human Resources section NDP 2000-2007 p 17.

The priorities for the Employment and Human Resource Development Operational Programme Will reflect those of the National Employment Action Plan and will be organised under four SubProgrammes to reflect the four pillars of the EU employment guidelines: Employability, Entrepreneurship, Adaptability and Equal Opportunities. The allocation is broken down as follows between the four pillars: Pillar 2000-2006 Allocation ( $f$ million)

Employability 4,631

Entrepreneurship 413

Adaptability 4,647

Equality 202

Total 9,893

Employability

The Employability Sub-Programme will comprise a combination of Social Inclusion measures in the education sector and labour market integration and training measures. The Social Inclusion measures targeted at disadvantaged people will include:

- Early Education;

- School Completion;

- Early Literacy;

- Third Level Access Programme;

- Traveller Education;

- Career Guidance.

Among the Labour market measures will be:

- Active Measures for the Long-term Unemployed and Socially Excluded;

- An Action Programme for Unemployed;

- Early School Leavers progression to employment;

- Skills and Sectoral Training for the Unemployed and Redundant Workers.

Entrepreneurship

The Entrepreneurship Sub-Programme will comprise:

- Management Training for SMEs and

- The Social Economy Scheme.

Adaptability

Under the Adaptability heading there will be measures for:

- Lifelong Learning including a Back to Education Initiative to complement the early interventions under the Employability Pillar;

- Skills Development;

\section{Extract NDP 2007-2013 p 20}

Priority III: Human Capital

Total investment under this Priority is as follows;

Human Capital Priority 2007-2013 \m Current Prices

Programme Total

Training \& Skills Development 7,718

Higher Education 13,017

Schools Modernisation \& Development 5,061

Human Capital Total 25,796

Ireland's track record in education investment has been fundamental to generating our economic success. The main objective of the proposed investment of $\backslash 25.8$ billion over the Plan period is to maintain access to the highest standards of education for all in our society, to meet the labour skills requirement of the future

and to focus investment in particular on developing the key Third Level Sector. Key features are: - Over $\backslash 2.8$ billion will be invested in training and skills development programmes, including employment training, apprenticeships, new skills training for adult workers and programmes for school leavers;

- Nearly $\backslash 4.9$ billion in training and development programmes for a wide range of groups, including lone parents, people with disabilities, Travellers, ex-offenders and other categories requiring special interventions (this will also support the goals in the social inclusion priority);

- $\backslash 13$ billion for Third-Level Infrastructure and for ongoing costs of the sector in the context of the promotion of strategic and structural development; and

- $\backslash 5$ billion in First and Second Level schools modernisation and development 


\section{Endnotes}

\footnotetext{
${ }^{1}$ Employability is a contested term. It has been related to: an individual's capacity to obtain and maintain fulfilling work; the capability to move self-sufficiently within the labour market; and the ability to realise potential through sustainable employment and knowledge, skills and attitude.

${ }^{2}$ See EU Commission document, 25/10/2006.

${ }^{3}$ Ronald Barnett (1999).

${ }^{4}$ National Competitive Council's report 2005, Ireland.

${ }^{5}$ Skills that can be utilised in various different employment sectors; they are generic but sometimes are categorised into soft and hard skills sets.

${ }^{6}$ The mainstreaming of this project will include the development of other Key Skills programmes, as Special Purpose Awards located on the NFQ levels 7, 8, 9 and 10.

7 'Critical self reflection' as defined by Barnett (1997: 90-101) is a concept related to critical theory and texts on emancipation, transformation and liberation.

${ }^{8}$ The specific, established, academic knowledge domains I explore are sociology, philosophy, psychology and areas of non-specific or fuzzy boundaries such as industrial relations, evaluation and management.

${ }^{9}$ Guba and Lincoln (1989) Fourth Generation Evaluation, Claims relate to positive aspects, concern relate to negative aspects and issues to mid ground aspects.

${ }^{10}$ Policy shapers are organisations that have reputation currency and the ability to utilise their expert knowledge in terms of research reports to lobby governments and affect the policy formulation process.

${ }^{11}$ See Forrier and Sels (2003).

12 The use of student/worker is not intended to depict a linear process of production, student learners for the labour process. We are deliberately non-prescriptive - students/workers can be employees, employers, entrepreneurs, researchers, artists and so forth. In essence the student/worker has the autonomy of choice to decide how and where they apply their employability.

13 For a summary of the approaches taken by France, Germany and other European countries, see Winterton et al. (2006: 1).

${ }^{14}$ UK Department of Education and Skills (2005).

${ }^{15}$ For a critique of the performance indicator approach relating to employability see Morley (2001) and Harvey (2001).

${ }^{16}$ The use of 'techno-rationality' here is a link to Habermas' concept of 'technical rationality' as a new ideology of work. We also allude here to the possible 'reification' of the student as a product for the new organisation of work.

17 See OECD (2006).

${ }^{18}$ The employability 'wish list' includes items such as loyalty, good sense of humour, compliant, obedience, respect for authority, flexibility, common sense, trusting and so forth.

${ }^{19}$ See Forfas (2005).

${ }^{20}$ NDP (2007-2013), launched on 22 January 2007, outlines a $€ 183.7$ bn investment and five priority areas: economic infrastructure, enterprise science and innovation, human capital and social inclusion.

${ }^{21}$ The Enterprise Strategy Group Report (2004).

${ }^{22}$ Commission of the European Communities (2005).

${ }^{23}$ Social capital and cultural capital as used here relate to the work of Bourdieu.

${ }^{24}$ See Patton (1997).

${ }^{25}$ This can lead to what Morley describes as 'underemployment'.

26 Author emphasis. Here we suggest the transition process that students encounter during their first engagement with work post student life. We do not include part-time work while studying or workers who become students as these are different transition processes.
} 